\title{
Comments on the paper by A. May "Micheliniidae and Cleistoporidae (Anthozoa, Tabulata) from the Devonian of Spain"
}

\author{
YVES PLUSQUELLEC \& ESPERANZA FERNÁNDEZ-MARTíNEZ
}

Plusquellec, Y. \& FernándeZ-MARTíneZ E. 2007. Comments on the paper by A. May "Micheliniidae and Cleistoporidae (Anthozoa, Tabulata) from the Devonian of Spain". Bulletin of Geosciences 82(1), 85-89 (3 figures). Czech Geological Survey, Prague. ISSN 1214-1119. Manuscript received January 22, 2007; issued March 30, 2007. • DOI 10.3140/bull.geosci.2007.01.85

Yves Plusquellec, Université de Bretagne Occidentale, UMR 6538 "Domaines océaniques", Laboratoire de Paléontologie, UFR Sciences \& Techniques, 6 av. Le Gorgeu - CS 93837, F-29238Brest cedex 3, France; Yves.Plusquellec@univ.brest.fr • Esperanza Fernández-Martínez, Área de Paleontología, Facultad de Ciencias Biológicas y Ambientales, Campus de Vegazana s/n, Universidad de León, 24071 León, Spain; e.fernandez@unileon.es

In our opinion the conclusions presented in the paper by Andreas May in Bulletin of Geosciences 81(3), 163-172 (2006) are unsatisfactory for three reasons concerning both method and results. Firstly, it is not productive to create new species for which the information about exact locality, stratigraphic position and age are imprecisely known. Secondly, it is very hazardous to attempt the identification of michelinid corals without examining thin sections, or at least acetate peels, and cleistoporids corals without convincing data on the filling of the corallites. And thirdly, we disagree with the generic and/or specific assignment of three out of five specimens.

Short comments are made in the following sections, in the context of related taxa. Four complementary figures (drawings) of sectioned material provide further information about these corals. This review of May's assignments was made possible thanks to the loaning of the specimens by Isabel Rábano Gutiérrez del Arroyo, director of the Museo Geominero (IGME, Madrid), who also allowed us to make the essential sections.

\section{Pleurodictyum problematicum Goldfuss, 1829}

We did not borrow the two specimens figured by May (2006, fig. 1A, B) because, in our opinion, they could be assigned to this species, which is not known in strata higher than the Lower Emsian. For example, an interesting loca- lity for this species is known in Celtiberia, where the specimens are preserved in calcite: North of Nogueras, Mariposas Formation, d4a $\beta$, Lower Emsian.

\section{Pleurodictyum elisabetae May, 2006}

The identification of Pleurodictyum-like corals is very problematic when the aboral side is unknown. In this case the specimens could belong to Pleurodictyum Goldfuss, 1829, Procteria Davis, 1887, Procterodictyum Plusquellec, 1993 or Amazonodictyum nom. nud. (Plusquellec 2006, unpublished thesis; type species Pleurodictyum amazonicum Katzer, 1903). Nevertheless, a more precise identification is possible in a few cases.

We have examined the two specimens (stock numbers 13D and 14D, Museo Geominero) figured by May (fig. 1C, D). They come from Tramacastilla de Tena (Huesca province). According to Valenzuela-Ríos \& Carls (1994) the succession in this area consists mostly of Pragian-Emsian calcareous rocks, overlain by an interval of shales, marlstones, and sometimes limestones, which have been dated as Emsian to Eifelian in age. The benthic fauna is particularly abundant in the Lower Eifelian part of this succession, but the age of the specimens remains conjectural.

In his description, May (2006, p. 166) indicates that the "internal moulds of the corallites do not show the longitudinal depression that is familiar [in] Pleurodictyum." This is not in accordance with the facts, as this structure can be clearly observed on his fig. 1C (compare with our Fig. 1A). Unfortunately another feature of the calicinal bottom moulds (a very essential one) was overlooked by May. On both sides of the axial depression of the corallites are numerous rounded sections (generally $0.25-0.30 \mathrm{~mm}$ ) which are the sections or pores in the basal plate. Thus the material does not belong to Pleurodictyum as asserted May, but more likely to Procteria (Granulidictyum).

The species - even belonging to Granulidictyum seems new, and its diagnostic feature is the presence of large and numerous mural pores (as indicated by May).

In our opinion the comparison with Pleurodictyum(?) parvum Dubatolova, 1960 does not contribute to our knowledge, and the possible relationship to Asian corals is not 

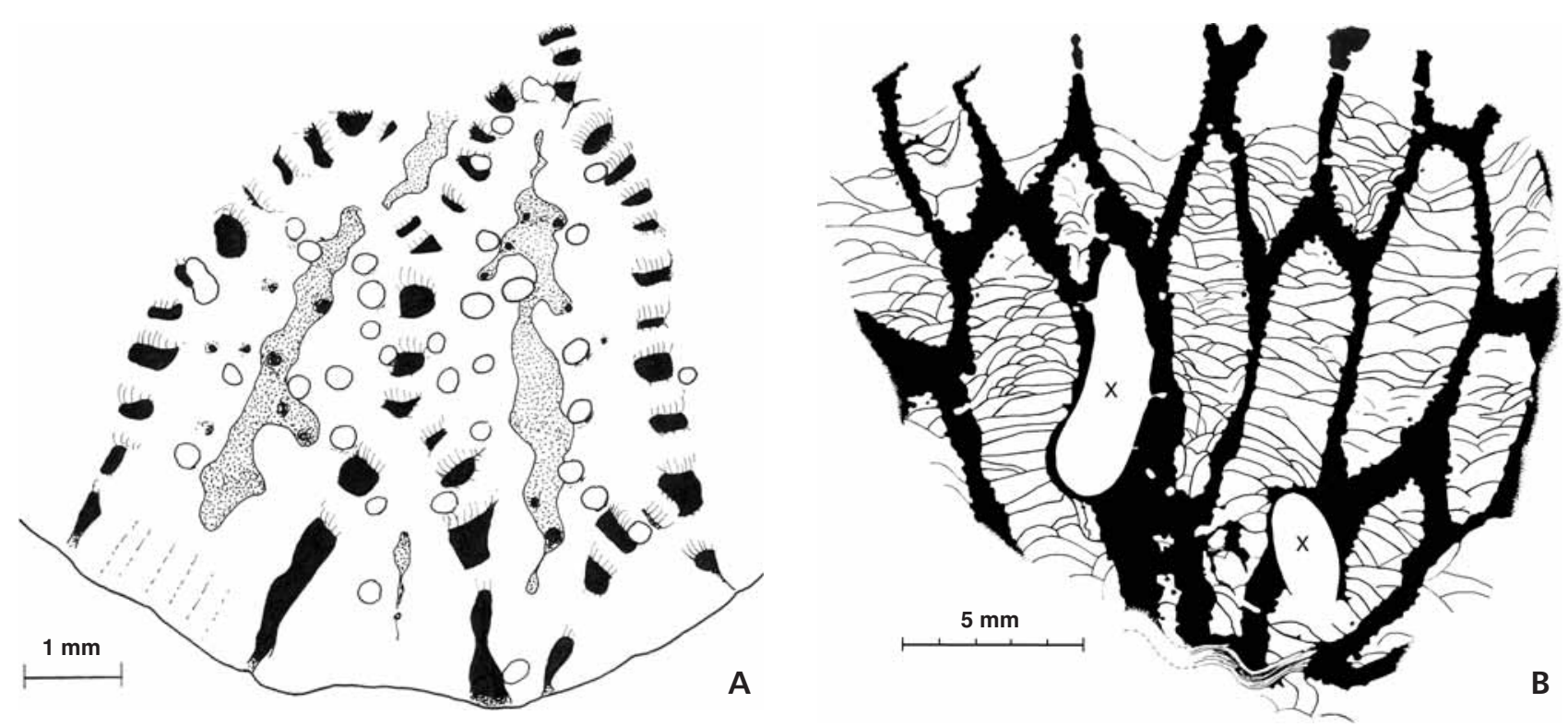

Figure 1. A - Procteria (Granulidictyum) elisabetae (May, 2006), holotype, stock No. 13D (= May 2006, fig. 1C, lower part). Drawing of the calicinal bottom of four corallites of the peripheral zone of the corallum showing, preserved as natural casts, the large and numerous mural pores, the strong and narrow longitudinal axial ridge (stippled area) and, on both sides of this structure, the numerous sections of the pores of the basal plate (open circle); the wall is in black. Note the poorly pronounced septal ridges on the margin of the left corallite. $\bullet$ B - Michelinia sp. stock No. 1111D, acetate peel A (same specimen as May 2006, fig. 1F-H). Longitudinal section in the corallum showing the remains of a brachiopod shell to which the coral was attached, a very well developed tabularium, a spinose wall, and the sections (x) of Hicetes.

demonstrated in greater detail than had been ascertained before this study. The generic and even familial assignation of Pleurodictyum(?) parvum remains impossible, as the original material consists of a badly made transversal section showing ordinary polygonal corallites and a natural cast that has nothing in common with Pleurodictyum.

At the end of his remarks, May (2006, p. 166) indicates that all attempts to find the publication of Dubatolova (1960) had failed. In fact it is easily accessible, but the species is described in a chapter by Vassiljuk et al. in a book edited by Markovsky (see the additional references).

In conclusion, the specimens 13D and 14D are to be assigned to Procteria (Granulidictyum) elisabetae (May, 2006).

\section{Michelinia guerangeri (Milne-Edwards \& Haime, 1851)}

We have examined the three specimens (stock numbers 801D, 1110D and 1111D, Museo Geominero) described by May (2006, fig. 1F-H).

As a preliminary remark regarding the microstructure, we disagree with the interpretations of May (and Oekentorp, in diverse papers cited in May 2006, p. 167). In the present letter, we only want to pose a few questions and make one remark.

If the lamellae result only from diagenetic alteration, why are the fibrous trabeculae preserved in the same wall with their original microstructure, or at least as rods in the stereoplasm?

Why do the so-called "cupules" of the lamellae, and more clearly of the microlamellae, always have their concavity invariably facing the lumen i.e. the polyp?

Why do we never find "Michelinia" with divergent lamellae downwards from bottom to top in a colony, even though we find the opposite setting in Praemichelinia?

Following Nothdurf \& Webb (2003), we agree that the lamellae and the microlamellae are not necessarily biocrystals, but could represent originally fibrous units that survived due to the surrounding organic matrix, "and hence, their use in systematics may be supported" (Nothdurf \& Webb 2007).

However, considering only the morphology and the structural features of the specimens of Colle (1111D and $1110 \mathrm{D}, 801 \mathrm{D}$ is probably distinct), their assignment to the species guerangeri is not satisfactory.

This Armorican species is approximately globular in shape and apparently devoid of "epitheca", while in the Spanish specimens there are two distinct areas with aboral surfaces showing well developed growth wrinkles. Moreover, the corallum is strongly (1110D) or slightly (1111D) flattened in the latter.

The axial section (taken from the well preserved specimen 1111D, and the partly silicified 1110D) shows that the comparison strictly concerns Praemichelinia guerangeri guerangeri because the wall bears numerous trabeculae. The wall is very spiny, and has the same spine density from 

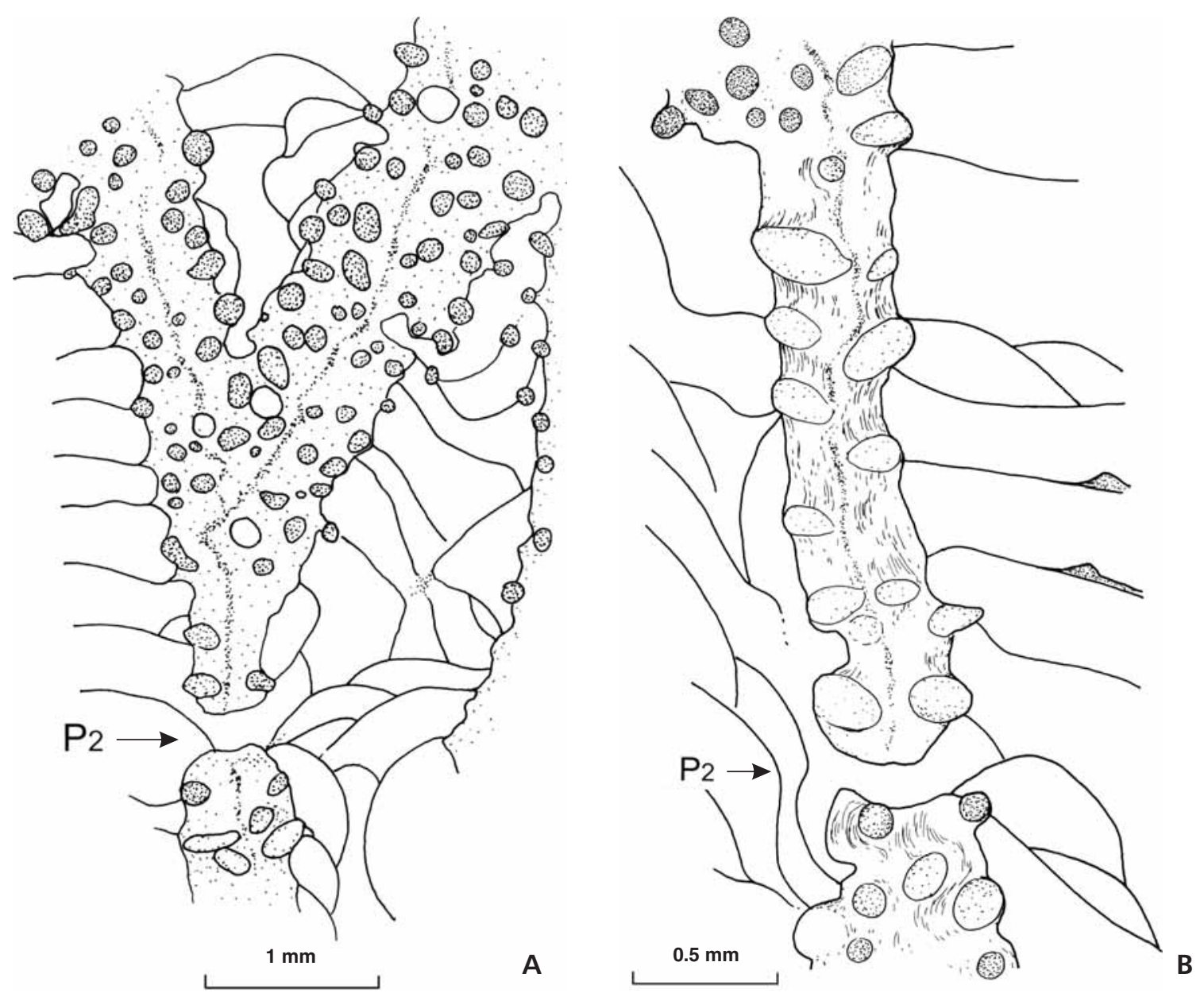

Figure 2. Michelinia sp. stock No. 1111D, acetate peel B. Enlarged view of the wall in longitudinal section. Note the numerous sections of trabeculae protruding in the lumen as spines ( $\mathrm{A}$ and B) and sections of mural pores P2 (arrows). On acetate peels in transmitted light, the trabeculae appear as dark grey in the transverse sections, but show light-grey hues in the axial sections. On B note the lamellar sclerenchyme with the lamellae arranged parallel to the median "dark" line.

bottom to top in the colony; this feature is directly linked with the very high number of trabeculae (Fig. 2). In Preamichelinia guerangeri guerangeri the trabeculae are lacking in some areas of the corallum.

The section shows numerous convex tabellae of various sizes, and only a few complete tabulae (Fig. 1B). In Preamichelinia guerangeri guerangeri the tabularium is less dense and the complete tabulae are more numerous. The diameters of the corallites seem to be smaller in the Spanish species.

The comparison of the section illustrated here (Fig. 1B) with the figures of Preamichelinia guerangeri guerangeri given by Lafuste \& Plusquellec (1980, especially in figs 42-44) does not unreservedly support the assignment proposed by May. Moreover, an important feature of the Colle specimen is that the lamellae are parallel to the median "dark" line. In our opinion, this specimen belongs to Michelinia sensu stricto, and cannot be compared with guerangeri, which is assigned to Praemichelinia.
In addition, the species of Colle is clearly associated with Hicetes, while this character is not obvious in $P$. guerangeri. Nevertheless, a careful examination of fig. 44 of Lafuste \& Plusquellec (1980) exhibits a bad section of a worm gallery (not indicated in the figure caption) in the central part of $44 \mathrm{a}$ and the lower central part of $44 \mathrm{~b}$.

The well developed "epitheca", the more or less flattened shape of the corallum, the presence of Hicetes, and the type of microstructure are consistent with some of the characteristics of Kerforneidictyum Lafuste \& Plusquellec, 1976. However, the presence of Hicetes is not diagnostic by itself, and the tabularium is much more developed here than in Kerforneidictyum, in which the tabulae are scarce or missing.

In the Colle section, in the lower part of La Pedrosa Formation, Lower Emsian, F. Soto has collected some small flattened colonies that are similar to the so-called guerangeri sensu May by the size of their corallum and 


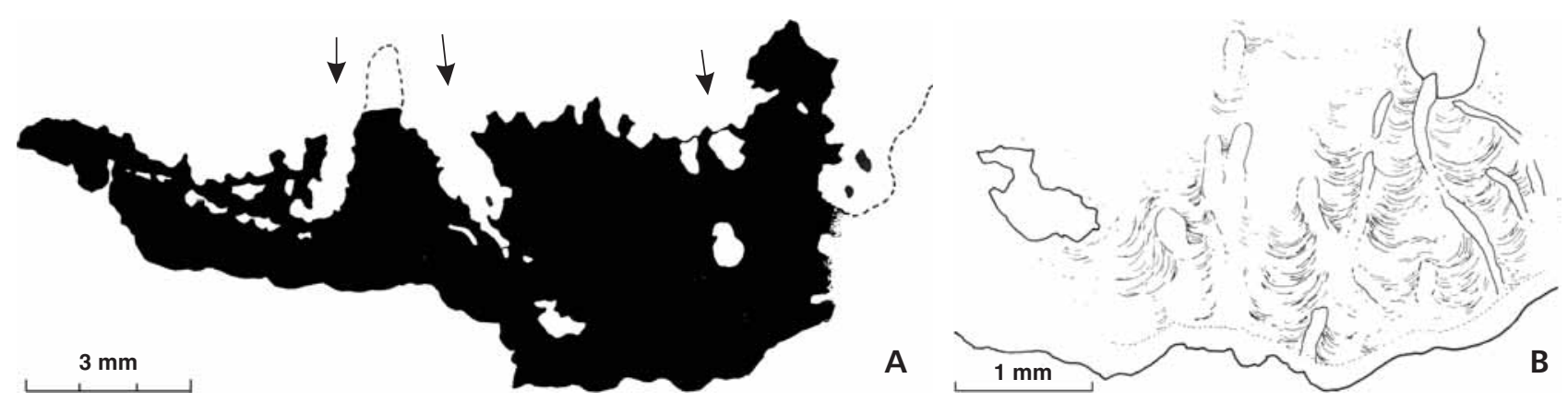

Figure 3. Vaughaniopsis cf. lafusti Plusquellec, 2006 nom. nud. (= May 2006, fig. 1K). • A - longitudinal grinding in two marginal corallites (acetate peel) showing, especially in the right corallite (axial section), the deep peripheral trough topped in some places by the skeleton and thus becoming a ring canal (arrows). On the left corallite the section is tangential to the wall and creates the false appearance of a spongy structure. $\bullet \mathrm{B}-$ microstructure of the basal plate showing lamellae deflected around trabeculae.

corallites, their lamellae parallel to the median "dark" line, their numerous spines/trabeculae, and the presence of Hicetes. But they differ in having much less numerous tabulae and tabellae, and they probably represent a distinct species.

In conclusion, the specimens $1111 \mathrm{D}$ and $1110 \mathrm{D}$ are to be identified as Michelinia s.s. sp.

\section{Procteria (Granulidictyum) granulifera (Schlüter, 1889)}

We have not seen these specimens, but their description and figuration are consistent with the diagnosis of Granulidictyum and the very common species granuliferum or gr. granuliferum. We only wish to point out that Procteria $(G$.) granuliferum is known in Celtiberia, Montforte Formation (lower part), Eifelian (partitus zone).

\section{Cleistopora smythi Le Maître, 1952}

We have only seen the specimen (stock number 41D, Museo Geominero) described by May (2006, fig. 1J, K).

As underlined by May, the case of Michelinia/Praemichelinia is not similar to that of Paracleistopora Plusquellec, 1973 because the latter is not based mainly on microstructural differences with Cleistopora Nicholson, 1888. May is apparently unaware of the publication of Plusquellec (1973). In the original diagnosis, Plusquellec gave the following description (translated from French): corallum discoid, pleurodictyform, with few corallites, without mural pores. Irregular spongy tissue, poorly developed, located in the initial corner of the corallites, optional (?) on the peripheral corallites. Tabulae are not present. Calicinal bottom with granules of various sizes. Septal ridges more or less developed. All of these features allow the clear distinction of Cleistopora from Paracleistopora. In the former, corallites are numerous, mural pores are present, the spongy tissue is well developed within the entire corallite and in all the corallites, tabulae are present, and the ornamentation of the calicinal bottom is not granular but vermicular. Finally, the diagnosis ends with some data on the microstructure: lamellar sclerenchyma with "holacanths" trabeculae. The genus Cleistopora is entirely fibrous.

We now return to Cleistopora smythi sensu May, 2006. Familiarity the Cleistoporidae makes it surprising that the specimen from Las Peñotas may has been assigned to smythi for the following reasons: 1) the structure of the corallum differs from that of the known species of Paracleistopora in which a bilateral symmetry is easily recognizable (generally 3 or 5 corallites), and 2) the granulation of $P$. smythi is much more minute, and the outlines of the granules are not irregular.

An acetate peel we made from the section exposed in May's fig. 1K gives significant results (Fig. 3). Contrary to May's assertion, the corallites are not "filled by a spongy mass." The central area of the corallites, which is in fact a thick basal plate, is massive and its peripheral part, close to the wall and mainly in the initial corner, is occupied by a trough-like structure. This structure is spiny and exhibits some small tabulae. In some places it evolves in a probably incomplete ring canal (only seen in transverse section).

The microstructure of the basal plate consists of long trabeculae embedded in lamellar sclerenchyme (Fig. 3B). The same microstructure appears in the wall, but the trabeculae are arranged in a fan-like manner. The median "dark" line is apparently lacking.

In our opinion, the specimen described as C. smythi clearly belongs neither to Cleistopora nor to Paracleistopora, but to a new unpublished genus - close to Ligulodictyum Plusquellec, 1973 and Vaughania Garwood, 1913 - called Vaughaniopsis nom. nud. (Plusquellec 2006, unpublished thesis).

The type species of this genus, Vaughania lafusti n. sp. nom. nud., shows a slightly different microstructure: the 
lamellar sclerenchyme is reduced to a rather narrow sheet around the trabeculae in the proximal part of the basal plate, while the trabeculae may be contiguous in its upper part. Thus the microstructural variations in this genus are identical to those observed in Ligulodictum (see Lafuste et al. 1993, fig. 3).

$V$. lafusti is known in the Pragian of the Anti-Atlas in Morocco, in the kindlei conodont zone. Specimen 41D bears a chonetid valve in one of its corallites. Racheboeuf (pers. comm.) identified a pedicle valve of Ctenochonetes Racheboeuf, 1976, the form of which could be referred to as a member of the group of species $C$. jouannensis Garcia-Alcalde \& Racheboeuf, 1975 - Cibericus Racheboeuf, 1981, known from Upper Lochkovian to "middle" Pragian. Thus V. cf. lafusti is likely to be "middle" Pragian in age, certainly not Emsian/Couvinian.

In conclusion, specimen $41 \mathrm{D}$ is here assigned to Vaughaniopsis cf. lafusti Plusquellec, 2006.

Although the specimen described by May does not belong to Paracleistopora, the genus is already known from two different regions of Spain (coll. Y.P. and F. Soto): 1) The Cantabrian Mountains, in the Palentine nappes (Abadia Formation, Lower Emsian) and in the Fold and Nappes Region (Valporquero Formation, Upper Emsian), and 2) Celtiberia (Mariposas Formation, Lower Emsian and Early Upper Emsian).

Due to what we believe to be the erroneous assignment of most of the material, and the imprecise stratigraphical information, we find that May's conclusions presented in the discussed paper do not contribute to the knowledge of the tabulate corals in Spain and must be perceived as problematic.

\section{References}

The following bibliography is only additional (see May 2006).

LAfuste, J. \& Plusquellec, Y. 1976. Kerforneidictyum n. gen. (Tabulata, Dévonien): morphologie et microstructure. Bulletin de la Société Géologique de France 18(6), 1699-1711.

NothduRfT, L.D. \& WeBB, G.E. 2003. "Shingle” microstructure in scleractinian corals: a possible analogue for lamellar and microlamellar microstructure in Paleozoic tabulate corals. In Hubmann, B., Piller, W.E., Rasser, M. \& Latal, C. (eds) $9^{\text {th }}$ International Symposium on Fossil Cnidaria and Porifera. Berichte des Institutes für Geologie und Paläontologie der Karl-Franzens-Universität Graz/Austria 7, Abstracts, 75.

NothduRfT, L.D. \& WebB, G.E. 2007. In press. "Shingle" microstructure in scleractinian corals: a possible analogue for lamellar and microlamellar microstructure in Paleozoic tabulate corals. Proceedings of the $9^{\text {th }}$ International Symposium on Fossil Cnidaria and Porifera, Österreichische Akademie der Wissenschaften, Schriftenreihe Erdwissenschaftlichen Kommissionen 17.

PLUSQUELLEC, Y. 2006. Histoire naturelle des pleurodictyformes (Cnidaria, Tabulata, Dévonien) du Massif armoricain et des régions maghrébo-européennes principalement. Thèse inédite, Brest.

VAlenZuela-Rios, J.I. \& CARLS, P. 1994. Conodontos e invertebrados del Devónico Medio del Valle de Tena (Pireneos Aragoneses). Coloquios de Paleontologia 46, 43-59.

Vassiljuk, Y., Dubatolova, A.I., Kim, O.P., Kovalevsky, O.P., LELESHUS, I.A., TCHERNOVA, I.A. \& TCHEKHOVIITCH, V.D. 1960. Klass Anthozoa, Podklass Tabulata, 173-213. In MARKovsKy, B.P. (ed.) Novye vidy drevnikh rasteny i bespozvonotchnykh SSSR I. Vsesoyuznyi Nauchno-Issledovatelskii Geologicheskii Institut, Moscow (in Russian). 